\title{
Coleopterans prospection associated to forest ecosystems of Swietenia macrophylla (King), Eastern Amazonia
}

\section{Prospecção de coleópteros associados a ecossistemas florestais de Swietenia macrophylla (King), Amazônia Oriental}

\author{
Ruy Guilherme Correia ${ }^{*}$; Francisco de Assis Oliveira ${ }^{2}$; Leandro Silva de Souza \\ Raphael Lobato Prado Neves ${ }^{4}$; Jéssy Anni Vilhena Senado5; Joyse Tatiane Souza \\ dos Santos $^{6}$; Telma Fátima Vieira Batista ${ }^{7}$
}

\begin{abstract}
Few research on the entomofauna associated to forest plantations with Swietenia macrophylla (King) in Brazil has been reported. The aim of this study was to analyze the Coleoptera communities in forest ecosystems with $S$. macrophylla, Brazilian mahogany, with emphasis on the diversity of families and the main functional groups. The insects were collected through pitfall traps in three forest ecosystems: monoculture, consortium and forest enriched with Brazilian mahogany, during dry and rainy periods in two consecutive years. The identification of the captured insects occurred in the entomology laboratory of the Federal Rural University of Amazonia. The analysis was performed through Past Paleontological Statistic 3.14 and ANAFAU, where the difference was considered significant only when $p \leq 0.05 .11,358$ specimens from 21 families were captured, of which 8,058 were sampled in the rainy season and 3,299 in the dry season. There was influence of seasonality and types of forest ecosystems during collection. The families Nitidulidae, Staphylinidae, Carabidae and Meloidae presented greater abundance and richness in the complex ecosystems. Anobiidae, Cerambycidae, Bostrichidae, Brentidae, Buprestidae, Curculionidae, Elateridae, Chrysomelidae and Lagriidae were considered to be pests and common to all studied ecosystems; however, the families Nitidulidae, Scarabaeidae, Tenebrionidae and Passalidae had the function of decomposers; Carabidae, Coccinellidae, Histeridae, Meloidae, Staphylinidae, Cantharidae and Hydrophilidae were the predators.
\end{abstract}

Key words: Biodiversity. Insects. Brazilian mahogany.

\section{Resumo}

Poucas pesquisas sobre a entomofauna associada a plantios florestais com Swietenia macrophylla (King), no Brasil, tem sido reportadas. Pretendeu-se estudar a prospecção de comunidades de Coleópteros em ecossistemas florestais com S. macrophylla, mogno brasileiro, com ênfase na diversidade de famílias e dos principais grupos funcionais. A coleta dos insetos foi através de armadilhas do tipo "pitfall traps" em três ecossistemas florestais: monocultivo, consórcio e floresta enriquecida com mogno brasileiro,

\footnotetext{
Dr. em Ciências Florestais, Universidade Federal Rural da Amazônia, UFRA, Belém, PA, Brasil. E-mail: cciigg25@yahoo.com.br

Prof. Dr., UFRA, Belém, PA, Brasil. E-mail: fdeassis@gmail.com

3 Eng ${ }^{\circ}$ Florestal, UFRA, Belém, PA, Brasil. E-mail: leandro_ssd@live.com

4 Discente, Curso de Doutorado, Programa de Pós-Graduação em Ciências Florestais, UFRA, Belém, PA, Brasil. E-mail: pradu_@ hotmail.com

5 Enga Florestal, UFRA, Belém, PA, Brasil. E-mail: jessyanni@hotmail.com

$6 \mathrm{Dr}^{\mathrm{a}}$ em Ciências Ambientais, Universidade Federal do Pará, UFPA, Belém, PA, Brasil. E-mail: joysetaty@hotmail.com

7 Prof ${ }^{\mathrm{a}} \mathrm{Dr}^{\mathrm{a}}$, UFRA, Belém, PA, Brasil. E-mail: telmabatistacoelho@yahoo.com.br

* Author for correspondence
} 
durante os períodos seco e chuvoso em dois anos consecutivos. A identificação dos insetos capturados ocorreu no laboratório de entomologia da Universidade Federal Rural da Amazônia. As análises foram realizadas através dos programas Past Paleontological Statistic 3,14, e ANAFAU, onde a diferença foi considerada significativa apenas quando $\mathrm{p} \leq 0,05$. Foram capturados 11.358 espécimes de 21 famílias, sendo 8.058 indivíduos no período chuvoso e 3.299 no seco. Houve influência da sazonalidade e dos tipos de ecossistemas florestais durante a coleta. As famílias Nitidulidae, Staphylinidae, Carabidae e Meloidae apresentaram maior abundância e riqueza nos ecossistemas mais complexos. Anobiidae, Cerambycidae, Bostrichidae, Brentidae, Buprestidae, Curculionidae, Elateridae, Chrysomelidae e Lagriidae foram as famílias consideradas pragas e comuns a todos os ecossistemas estudados, entretanto, as famílias Nitidulidae, Scarabaeidae, Tenebrionidae e Passalidae tiveram função de decompositores; Carabidae, Coccinellidae, Histeridae, Meloidae, Staphylinidae, Cantharidae e Hydrophilidae foram os predadores.

Palavras-chave: Biodiversidade. Insetos. Mogno brasileiro.

\section{Introduction}

Brazilian mahogany (Swietenia macrophylla King) is the most commercially valuable Meliaceae species in the international timber market and one of the most exploited plant species in Brazil (SANTOS et al., 2008a). However, mahogany monoculture is jeopardized by severe pest attacks, which limit tree growth and cause excessive damage and plant death (ROCHA; QUOIRIN, 2004).

In Brazil, the exact number of mahogany plantations is not known, and a few cultivation areas have been studied in the northern region, especially in the state of Pará. Several mahogany cultivation attempts failed because of the low quality of the seedlings, low fertility of the Amazon soils, and the attacks of pests (SILVA et al., 2007a; CARVALHO, 2007).

The main insect pest that affects Brazilian mahogany plantations is the mahogany shoot borer Hypsipyla grandella (Lepidoptera), which is considered the main deterrent to reforestation with S. macrophylla (CARVALHO, 2007). Other insects, including those of the order Coleoptera, affect these plantations to a smaller extent (NAIR, 2007).

Among the invertebrates, several insects have been used as indicators of degradation of terrestrial ecosystems by their ability to develop even in small fragmented areas, where larger vertebrates do not occur (GARDNER et al., 2008; ENGELBRECHT, 2010). These insect species use specific resources and respond quickly to environmental changes (LEWINSOHN et al., 2005).

Biodiversity is high in tropical forests and, in these ecosystems, insect and microbial species are much more abundant than plant species (KAGEYAMA, 2008). Insects are used to assess the quality of forest systems because of their higher susceptibility to environmental changes, and different environmental conditions affect the abundance of insect communities (AZEVEDO et al., 2011).

The study of the abundance and diversity of the entomofauna is useful to evaluate environmental quality because these species participate in processes that affect the structure of the soil and environment (ROGER-ESTRADE et al., 2010; SANTOS et al., 2008b). Insects of the order Coleoptera have been well studied. This order has approximately 350,000 described species and is the insect group with the highest functional diversity, including predators, decomposers, pollinators, and pests of agricultural and forest crops (GANHO; MARINONI, 2005).

Many studies evaluated the behavior of beetles in different habitats (GANHO; MARINONI, 2006). However, few studies to date evaluated coleopteran diversity in areas reforested with S. macrophylla.

Investigating the beetle fauna comprised of the most abundant families or species help minimize the difficulty in identifying the least abundant taxa and increase the knowledge of this order in 
a given ecosystem. It is important to emphasize that assessing the relationship between beetle populations and the environment at the taxonomic level may help identify certain insect groups as indicators of environmental conditions in reforested areas (GANHO; MARINONI, 2006).

The objective of this study is to evaluate coleopteran communities in three forest ecosystems containing S. machopylla in Eastern Amazon, with emphasis on the diversity of families and functional groups.

\section{Material and Methods}

The study was carried out in a commercial area in the municipality of Aurora do Pará (latitude, $2^{\circ} 10^{\prime} 00^{\prime \prime} \mathrm{S}$; longitude, $\left.47^{\circ} 32^{\prime} 00^{\prime \prime} \mathrm{W}\right)$, state of Pará, Brazil. Four collections were performed in different periods two in the rainy season (February and April) and two in the dry season (July and November) for two consecutive years.

Each evaluated forest ecosystem had 1 hectare, age of 13 years, distance of $1,000 \mathrm{~m}$ from each other, and the following composition: ecosystem 1 (latitude, 2॰16’07' S, longitude, 4758'04” W) was an intercropping system of $S$. macropylla with other Meliaceae species, including Australian cedar (Toona ciliata, Max Joseph Roemer, 1846), African mahogany (Khaya ivorensis, Auguste Jean Baptiste Chevalier, 1909), and nim (Azadirachta indica, Adrien-Henri de Jussieu, 1830); ecosystem 2 (latitude, 2 ${ }^{\circ} 17^{\prime} 09^{\prime \prime} \mathrm{S}$; longitude, 47 57' 06" W) was a monoculture system of $S$. macropylla; and ecosystem 3 (latitude, $2^{\circ} 16^{\prime} 12^{\prime \prime} \mathrm{S}$; longitude, $47^{\circ} 59^{\prime} 01^{\prime \prime}$ W) was an area reforested with $S$. macropylla (Figure 1).

Figure 1. Location of the research area with the forest ecosystems of S. macropylla in Aurora do Pará - PA.

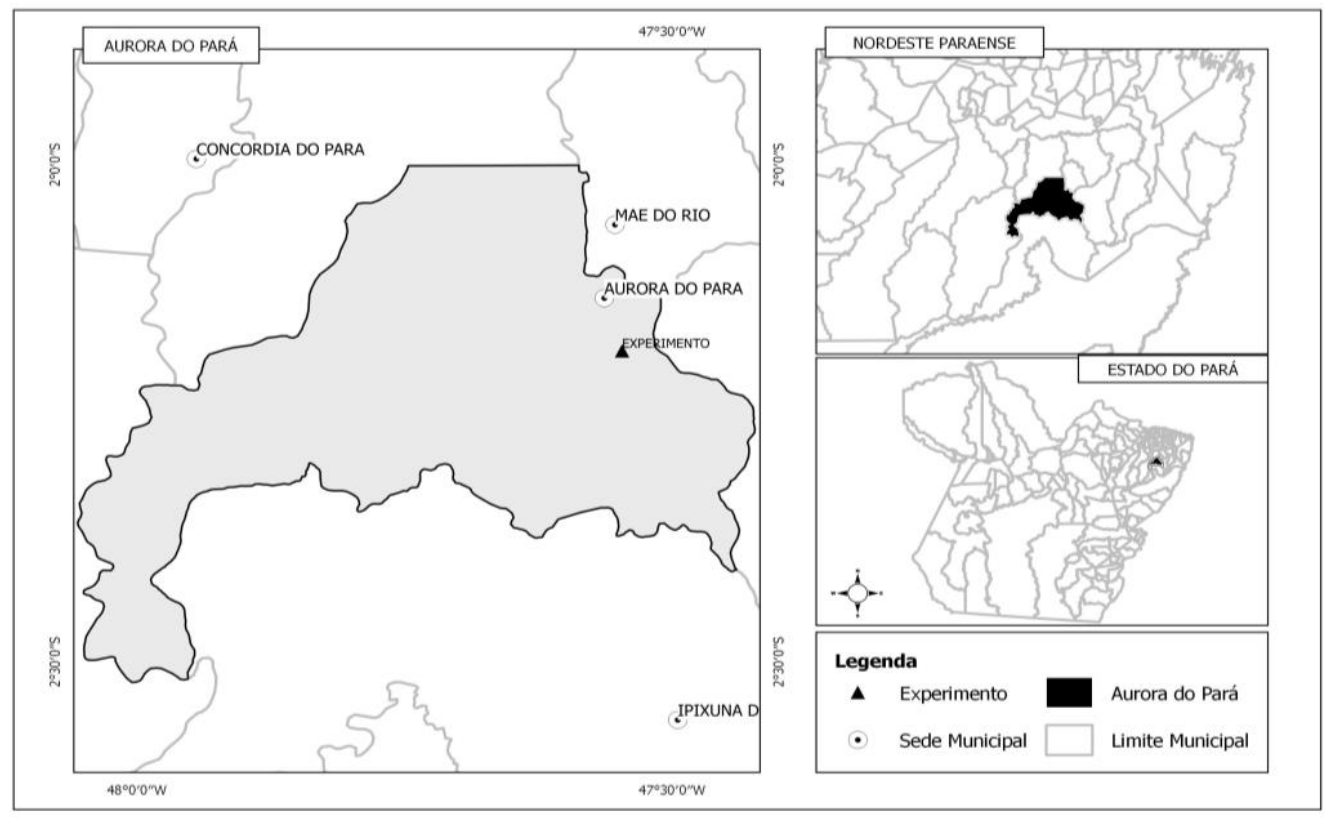

The specimens were collected using pitfall traps consisting of $500 \mathrm{~mL}$-plastic bottles measuring $127 \mathrm{~mm}$ in height and containing $100 \mathrm{~mL}$ of $70 \%$ alcohol and detergent. Each trap was buried in the upper layer of the soil (SILVA et al., 2007b).
The traps remained in the field for 2 days in each evaluated month and were removed and relocated in the evaluated ecosystems in the subsequent months. Each ecosystem was divided into quadrants $(50 \times 50$ $\mathrm{m})$, and each quadrant contained 20 traps (Figure 2). 
Figure 2. Spatial arrangement of the installation of pitfalls in quadrants of forest ecosystems with S. macrophylla, Eastern Amazonia.

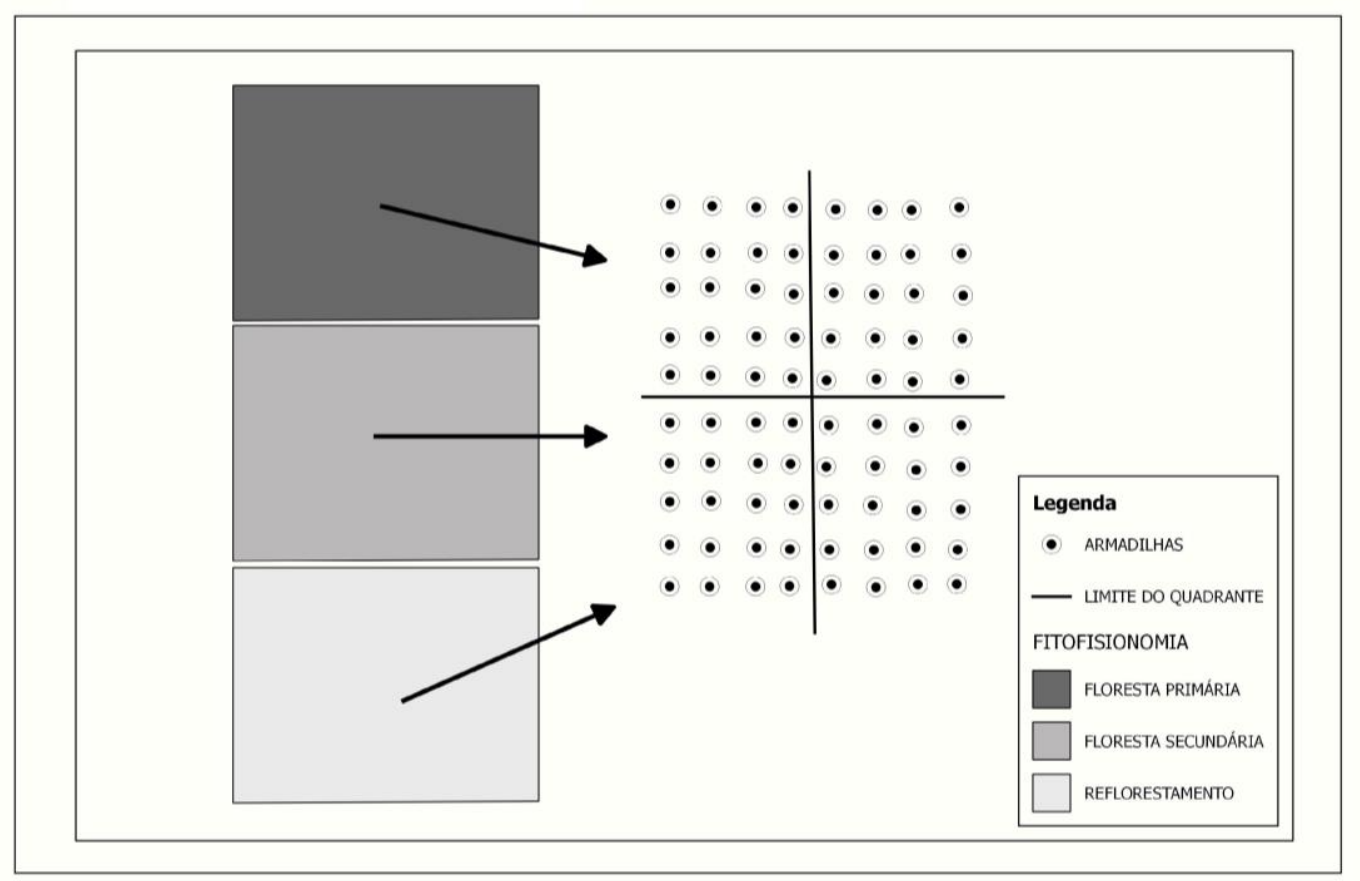

The insects were quantified and identified in temperature $\left({ }^{\circ} \mathrm{C}\right)$ and rainfall $(\mathrm{mm})$ were obtained families using identification keys as described from the National Institute of Meteorology (INMET, previously (TRIPLEHORN; JOHNSON, 2011; 2017), (Figure 3).

RAFAEL et al., 2011). The mean values of

Figure 3. Average temperatures $\left({ }^{\circ} \mathrm{C}\right)$ and rainfall $(\mathrm{mm})$ in the collection period of coleoptera. Northeastern Mesoregion of Pará.

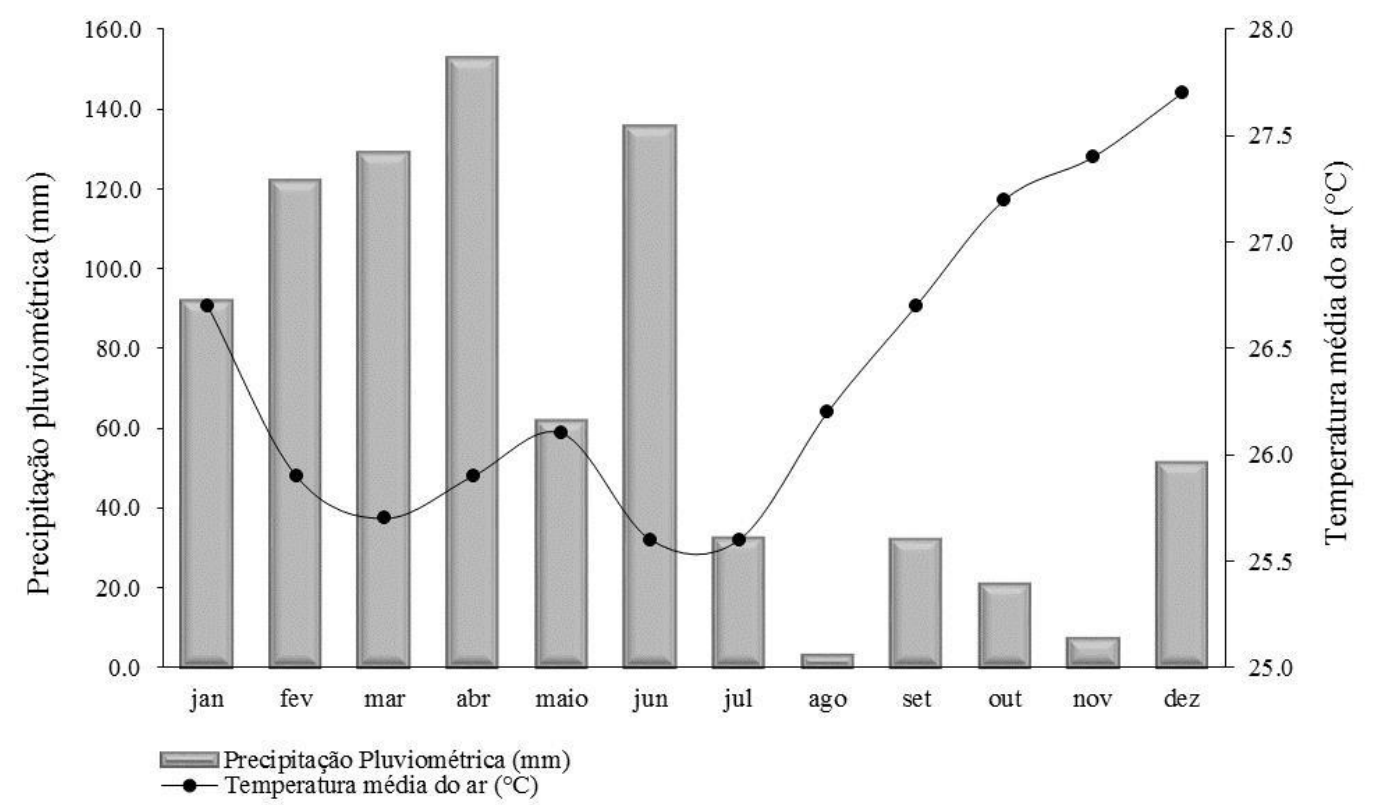


The abundance, richness, Shannon-Wiener diversity index, Margalef index, and Pielou equability index were calculated to determine the number of beetle families in each ecosystem. The Kruskal-Wallis test was used to assess the significance of the diversity values obtained with the Shannon-Wiener index. The Mann-Whitney test was used as the nonparametric version of the $t$-test for independent samples to evaluate the equality of the medians.

The uniformity in the abundance of specimens distributed between the sampled families was calculated using the equitability index (J'). Dunn's post-hoc test was used to assess the presence of significant differences in the abundance of the families in the three ecosystems.

The results were analyzed using statistical software Past Paleontological Statistic version 3.14 (HAMMER; HARPER, 2006) and software ANAFAU version 2.0 (MORAES et al., 2003), and p-values smaller than $5 \%$ were considered significant.

\section{Results and Discussion}

A total of 11,358 coleopteran specimens from 21 families were collected. The families Nitidulidae, Meloidae, Staphylinidae, Carabidae, and Bostrichidae contained the largest number of collected specimens, with a relative abundance of $60 \%$ in the rainy season and $49 \%$ in the dry season (Table 1). The relative abundance of the other families in these two seasons was $40 \%$ and $51 \%$ of the total collected specimens, respectively.

The family Nitidulidae was more abundant in the intercropping system and reforested area relative to the other identified families (Table 1). Similar results were obtained by Bossões (2011) and Petroni (2008). Azevedo et al. (2016) found that the family Nitidulidae was abundant in humid forest environments during the period of highest rainfall, which agrees with the present results in Eastern Amazon.
The families Nitidulidae, Meloidae, Staphylinidae, Carabidae, and Bostrichidae are abundant in several environments, including primary and secondary forests, pastures, and agricultural areas (ZALAZAR; SALVO, 2007; LIMA et al., 2010, 2013). However, Santos et al. (1979) pointed out that the higher abundance of specimens from a few coleopteran families might be associated with environmental factors, including lower floristic diversity, because the richness of coleopteran species and families is affected by the degree of floristic diversity, as observed in the intercropping system and reforested area.

The families Carabidae, Scarabaeidae, Meloidae, Staphylinidae, Tenebrionidae, Curculionidae, Coccinellidae, Elateridae, Nitidulidae, and Chrysomelidae were very abundant in forest ecosystems, as previously reported (LIMA et al., 2010). The diversity of these coleopterans is justified by the effect of the local plant structure in different environments (LIMA et al., 2010).

In the rainy season, the monoculture presented the highest number of specimens in the family Bostrichidae (283), which are wood-boring beetles and potential pests of mahogany plantations. However, the family Histeridae (235), which are predators of insect larvae, was also present, and increased representativeness of this family might be due to the presence of larvae of different beetle species.

The faunal indexes indicated the presence of different families in the three evaluated ecosystems. The monoculture presented the highest diversity and equitability indexes $\left(\mathrm{H}^{\prime}=2.78\right.$ and $\mathrm{E}^{\prime}=0.92$, respectively) when compared with the intercropping $\operatorname{system}\left(H^{\prime}=2.58\right.$ and $\left.E^{6}=0.84\right)$ and reforested area $\left(H^{\prime}=2.60\right.$ and $\left.E^{\prime}=0.85\right)$. These results indicate that these indexes may have been determined by the families Bostrichidae, Histeridae, Nitidulidae, Staphylinidae, Scarabaeidae, Carabidae, and Meloidae, which presented the larger number of specimens, especially in the rainy season (Table 2). 
Table 1. General distribution of abundance by coleopteran family collected in forest ecosystems with $S$. macrophylla, Eastern Amazonia, Brazil.

\begin{tabular}{cccccccccc}
\hline Families & $\mathrm{M}$ & $\mathrm{C}$ & $\mathrm{F}$ & Total $_{1}$ & $\mathrm{M}$ & $\mathrm{C}$ & $\mathrm{F}$ & Total $_{2}$ & TOTAL $^{2}$ \\
\hline Anobiidae & 0 & 11 & 18 & 29 & 0 & 13 & 5 & 18 & 47 \\
Bostrichidae & 283 & 267 & 77 & 627 & 63 & 48 & 34 & 145 & 772 \\
Brentidae & 27 & 39 & 27 & 93 & 9 & 21 & 17 & 47 & 140 \\
Buprestidae & 33 & 12 & 24 & 69 & 39 & 11 & 7 & 57 & 126 \\
Cantharidae & 42 & 19 & 37 & 98 & 13 & 1 & 15 & 29 & 127 \\
Carabidae & 107 & 391 & 289 & 787 & 37 & 140 & 101 & 278 & 1.065 \\
Cerambycidae & 57 & 59 & 76 & 192 & 30 & 35 & 32 & 97 & 289 \\
Chrysomelidae & 102 & 98 & 129 & 329 & 83 & 37 & 66 & 186 & 515 \\
Coccinellidae & 73 & 45 & 48 & 166 & 0 & 12 & 28 & 40 & 206 \\
Curculionidae & 76 & 151 & 16 & 243 & 51 & 106 & 56 & 213 & 456 \\
Elateridae & 174 & 37 & 43 & 254 & 62 & 58 & 30 & 150 & 404 \\
Erotylidae & 24 & 57 & 19 & 100 & 19 & 26 & 36 & 81 & 181 \\
Histeridae & 235 & 108 & 23 & 366 & 52 & 70 & 37 & 159 & 525 \\
Hydrophilidae & 34 & 51 & 3 & 88 & 4 & 4 & 21 & 29 & 117 \\
Lagriidae & 109 & 116 & 73 & 298 & 9 & 55 & 62 & 126 & 424 \\
Meloidae & 217 & 508 & 314 & 1.039 & 69 & 191 & 122 & 382 & 1.421 \\
Nitidulidae & 355 & 593 & 451 & 1.399 & 2 & 260 & 168 & 430 & 1.829 \\
Passalidae & 81 & 85 & 29 & 195 & 52 & 57 & 57 & 166 & 361 \\
Scarabaeidae & 221 & 119 & 119 & 459 & 91 & 87 & 56 & 234 & 693 \\
Staphylinidae & 233 & 398 & 386 & 1.017 & 40 & 249 & 83 & 372 & 1.389 \\
Tenebrionidae & 66 & 87 & 58 & 211 & 9 & 34 & 17 & 60 & 271 \\
\hline Insects total & 2.549 & 3.251 & 2.259 & 8.059 & 734 & 1.515 & 1.050 & 3.299 & 11.358 \\
\hline Families total & 20 & 21 & 21 & - & 20 & 21 & 21 & - & - \\
\hline
\end{tabular}

( $\mathrm{M}=$ monoculture; $\mathrm{C}=$ consortium; $\mathrm{F}=$ enriched forest $)$.

The faunal indexes indicated the presence of different families in the three evaluated ecosystems. The monoculture presented the highest diversity and equitability indexes $\left(\mathrm{H}^{\prime}=2.78\right.$ and $\mathrm{E}^{\prime}=0.92$, respectively) when compared with the intercropping $\operatorname{system}\left(H^{\prime}=2.58\right.$ and $\left.E^{6}=0.84\right)$ and reforested area $\left(H^{\prime}=2.60\right.$ and $\left.E^{\prime}=0.85\right)$. These results indicate that these indexes may have been determined by the families Bostrichidae, Histeridae, Nitidulidae, Staphylinidae, Scarabaeidae, Carabidae, and Meloidae, which presented the larger number of specimens, especially in the rainy season (Table 2). The Margalef index (DMg) indicated that the intercropping system and reforested area had the lowest family diversity but the highest family richness ( $\mathrm{DMg}=2.36$ and 2.46, respectively) (Table 2). However, the reforested area presented the highest family dominance $(\mathrm{D}=0.12)$. The diversity, equitability, Margalef, and dominance indices were not significantly different between these two ecosystems.

These results demonstrate that the insects sought habitats with higher forest diversity. Tabarelli et al. (2008) observed that ecosystems with lower plant diversity, including monocultures, natural forests, and recovered areas, presented low biotic diversity 
and less capacity to provide environmental services.

lowest faunal indexes in the monoculture in the This characteristic may have contributed to the present study.

Table 2. Diversity indices $(\alpha)$ of Coleoptera families in forest ecosystems. Eastern Amazonia, Brazil.

\begin{tabular}{cccc}
\hline & \multicolumn{3}{c}{ Forest ecosystems } \\
\hline Diversity indices & Monoculture & Consortium & Forest \\
\hline Shannon $\left(H^{\prime} \pm \mathrm{IC}\right)$ & $2,78 \pm 0,02 \mathrm{a}$ & $2,58 \pm 0,02 \mathrm{~b}$ & $2,60 \pm 0,03 \mathrm{a}$ \\
Equitability $\left(J^{\prime}\right)$ & $0,92 \mathrm{a}$ & $0,84 \mathrm{~b}$ & $0,85 \mathrm{~b}$ \\
Margalef $\left(D_{M g}\right)$ & $2,34 \mathrm{~b}$ & $2,36 \mathrm{a}$ & $2,46 \mathrm{a}$ \\
Dominance $(D)$ & $0,07 \mathrm{~b}$ & $0,10 \mathrm{a}$ & $0,12 \mathrm{a}$ \\
\hline
\end{tabular}

Averages followed by the same letter, in the same line, do not differ at the $5 \%$ level $(\mathrm{p} \leq 0.05), \mathrm{CI}$ : $\mathrm{H}$ 'confidence interval.

Many studies indicated that there were differences between environments with different levels of fragmentation or vegetation cover, and the higher vegetation coverage or complexity supports the development of exclusive communities, including more stable and diverse communities (EISENHAUER et al., 2008), confirming the present results.

The relatively higher diversity of the families Nitidulidae and Staphylinidae in the intercropping system and the reforested area may be due to the adaptation of these families to anthropic environments because the abundance of this group in native forests and degraded areas is high (MEDRI; LOPES, 2001). However, Athié and Paula (2002) have shown that the majority of the beetles of these families are decomposers, feeding preferentially on sap, fruit juice, and other fermented material.

The family Staphylinidae was very common in the evaluated ecosystems but presented specificities because some species are adapted to different habitats and most are considered predators in the larval and adult stages (TRIPLEHORN; JOHNSON, 2011). Specimens of this family were found in several agricultural crops, including cotton (COSTA et al., 2010), soybeans and maize (CIVIDANES; SANTOS-CIVIDANES, 2008; CIVIDANES et al., 2009), and watermelon (GOMES et al., 2012).
Nonetheless, this family has not been found to date in areas reforested with Brazilian mahogany.

The abundance of the family Carabidae in the two ecosystems with higher tree richness may be because areas with more diverse tree communities offer shelter and are more favorable to the development of carabids than areas with fewer tree communities and less diversified areas (VARCHOLA; DUNN, 2001), as observed in the monoculture system (Table 1).

Carabidae are the most frequent insects in agricultural areas when compared to natural and semi-natural areas. This family has unique habitat preferences, which are used to characterize these areas, and contains species living in forests, crops, and other habitats.

The beetles of the family Meloidae are defoliators and considered pests of cultivated plants (in contrast to larvae, which are predators) (GANHO; MARINONI, 2006). The occurrence of this family in the three forest ecosystems, especially in the intercropping system in the rainy season, may be related to a greater diversity of forest species, which increased food availability to polyphagous insects.

The analysis of climatic variables indicates that the rainy season presented a higher diversity of coleopteran specimens relative to the dry season in the two study years (Table 3). 
Table 3. Diversity indices of coleoptera families in different periods. Eastern Amazon, Brazil.

\begin{tabular}{ccc}
\hline & \multicolumn{2}{c}{ Periods } \\
\cline { 2 - 3 } Diversity indices & Dry & Rainy \\
\hline Shannon $\left(H^{\prime} \pm \mathrm{IC}\right)$ & $2,65 \pm 0,02 \mathrm{~b}$ & $2,75 \pm 0,02 \mathrm{a}$ \\
Equitability $\left(J^{\prime}\right)$ & $0,87 \mathrm{~b}$ & $0,90 \mathrm{a}$ \\
Margalef $(D M g)$ & $2,22 \mathrm{~b}$ & $2,46 \mathrm{a}$ \\
Dominance $(D)$ & $0,09 \mathrm{~b}$ & $0,07 \mathrm{a}$ \\
\hline
\end{tabular}

Means followed by the same letter, in the line, do not differ among themselves by the Tukey's post hoc test $5 \%$ (p $\leq 0.05)$, CI: H 'confidence interval.

Seasonality significantly affected the diversity of coleopteran families. In the dry season (November), rainfall was $10 \mathrm{~mm}$ and temperature was $27.5^{\circ} \mathrm{C}$. In the rainy season (April), rainfall was $160 \mathrm{~mm}$ and temperature was $26^{\circ} \mathrm{C}$. A $150-\mathrm{mm}$ increase in rainfall and a $1.5{ }^{\circ} \mathrm{C}$ decrease in temperature favored the increase in diversity, as demonstrated by the faunal indexes (Table 3 and Figure 3).

Several studies found that insect abundance was higher in the rainy season (OLIVEIRA; FRIZZAS, 2008; SILVA et al., 2011). However, the topography of each ecosystem may also have affected abundance.

Franco (2002) have shown that the greater presence of insects in agricultural and forest environments might be attributed to seasonality because rainfall supplies water and nutrients to the soil. Cornelissen and Fernandes (2001) indicated that these characteristics promoted plant development, increasing the quantity and quality of resources to insects. These same authors found that, in the rainy season, there was an increase in relative humidity, which decreased the risk of desiccation and dehydration and made the environment more favorable to the development and survival of freeliving herbivorous insects.

Studies on entomofauna have shown that the rainy season determines the population levels of insects in forest ecosystems, and this result was confirmed in the present study because there were significant differences in the number of specimens of a same family between the three ecosystems. Of the 21 identified families, $70 \%$ of the specimens belonged to seven families (Carabidae, Lagriidae, Scarabaeidae, Staphylinidae, Meloidae, Nitidulidae, and Bostrichidae), demonstrating that some families preferred one of the three evaluated forest ecosystems despite their widespread occurrence in different ecosystems.

There were significant differences in the abundance of coleopteran families between the ecosystems (Table 4).

Table 4. Abundance of coleopterofauna collected in forest ecosystems with S. macrophylla, Eastern Amazonia, Brazil.

\begin{tabular}{lccc}
\hline Forest ecosystems & Mann Whitney & Post hoc Dunn & Kruskal Wallis \\
\hline Monoculture (1) & $0.267^{\text {ns }}$ & $0.286^{\text {ns }}$ & \\
Consortium (1) & $0.005^{* *}$ & $0.004^{* *}$ & $p=0.004^{* *}(1)$ \\
Forest $\quad(1)$ & $0.006^{* *}$ & $0.167^{\text {ns }}$ & \\
\hline Monoculture (2) & $0.012^{* *}$ & $0.302^{\text {ns }}$ & \\
Consortium (2) & $0.003^{* *}$ & $0.001^{* * *}$ & $p=0.015^{*}(2)$ \\
Forest $\quad(2)$ & $0.018^{* *}$ & $0.028^{*}$ & \\
\hline Monoculture (3) & $0.850^{\text {ns }}$ & $0.849^{\text {ns }}$ &
\end{tabular}


continuation

\begin{tabular}{|c|c|c|c|}
\hline Consortium (3) & $0.066^{\mathrm{ns}}$ & $0.065^{\mathrm{ns}}$ & $p=0.080^{\text {ns }}$ \\
\hline Forest & $0.045^{*}$ & $0.042 *$ & \\
\hline Monoculture (4) & $0.969^{\mathrm{ns}}$ & $0.939^{\mathrm{ns}}$ & \\
\hline Consortium (4) & $0.979^{\mathrm{ns}}$ & $0.989^{\mathrm{ns}}$ & $p=0.996^{\mathrm{ns}}$ \\
\hline Forest & $0.939^{\mathrm{ns}}$ & $0.949^{\mathrm{ns}}$ & \\
\hline
\end{tabular}

(1) = rainy period of 2015. (2) = dry period of 2015. (3) = rainy period of 2016. (4) = dry period of 2016.

$(*) \mathrm{p}<0.05$ of significant difference, $(* *) \mathrm{p}<0.01$ of significant difference, $(* * *) \mathrm{p}<0.001$ of significant difference, (ns) not significant.

The Kruskal-Wallis, Mann-Whitney, and Dunn post-hoc tests confirmed the results of faunal indexes, in which the environments with the highest abundance, diversity, equitability, richness, and dominance presented the highest floristic richness, including the intercropping system and reforested area. The results in the intercropping system in the rainy season of the first year of collection were more significant $(p=0.003$ and $p=0.001)$.

The greater diversity of tree species in an ecosystem may favor higher production of organic matter from litter, which provides more favorable habitats for biotic development whereas monoculture depends on a single forest species for nutrient cycling and leads to the low production of organic matter (RAFAEL et al., 2011).

Monoculture forests have unique landscapes and microclimatic characteristics, including higher light intensity, wind speeds, and thermal amplitude (RODRIGUES; MARCHINI, 2000). These characteristics promote a decrease in insect biodiversity (PRIMACK; RODRIGUES, 2001) and may have contributed to the lower abundance of coleopteran families in this ecosystem.

Thomazini and Thomazini (2000) reported that secondary forests harbored a high diversity of insects, including Coleoptera, confirming the results of the present study. These authors found that the search for resources such as organic matter might stimulate the relocation of beetles to forest environments, avoiding competition in poorer areas for resources vital for insect development.

The following classification was obtained during family grouping by function: predators (seven families), pests (nine families), pollinators (one family), and decomposers (four families) (MOORE et al., 1988) (Table 5).

Table 5. Functional groupings according to (Correia 2016) of coleopterofauna families collected in reforestation areas with S. macrophylla, Eastern Amazonia, Brazil.

\begin{tabular}{cccc}
\hline Predators & Pests & Pollinator & Decomposers \\
\hline Carabidae & Anobiidae & Erotylidae & Nitidulidade \\
Coccinellidae & Cerambycidae & & Scarabaeidae \\
Histeridae & Bostrichidae & Tenebrionidae \\
Meloidae & Brentidae & Passalidae \\
Staphylinidae & Buprestidae & \\
Cantharidae & Curculionidae & \\
Hydrophilidae & Elateridae & \\
& Chrysomelidae & & \\
& Lagriidae & & \\
\hline
\end{tabular}


In the three forest ecosystems, there was a predominance of families with characteristics of pests and predators, demonstrating that the ecosystems harboring $S$. macrophylla have a large diversity of functional groups of coleopteran families.

This high variability in behavior indicates that these insects play essential roles in different ecosystems and participate in several biological processes fundamental to the functioning of forest systems, including decomposition of organic matter, maintenance of the soil structure, pollen transfer between plants, seed dispersal, and self-regulation of insect populations, including phytophagous arthropod pests (AGUIAR-MENEZES; AQUINO, 2005).

Predator beetles can control populations of other insects. Several families, including Coccinellidae, are important predators of aphids, which attack forest species (COULSON; WITTER, 1984).

Carabidae, Histeridae, Meloidae, Staphylinidae, and Cantharidae are predators and are essential for the biological control of pests of agricultural and forest systems (AGUIAR-MENEZES; AQUINO, 2005).

Scarabaeidae is a diverse group of beetles and participates in several ecological functions, including the reintroduction of decomposing organic matter to the soil, increase in soil permeability and aeration, control of fly species that are harmful to crops and livestock breeding, secondary seed dispersal, control of ants (Atta sp.), and pollination (SILVEIRA et al., 2006; NICHOLS et al., 2008).

\section{Conclusions}

The coleopteran fauna associated with monoculture systems, intercropping systems, and areas reforested with $S$. macrophylla is diversified. Twenty-one insect families, including Nitidulidae, Staphylinidae, Carabidae, and Meloidae, presented higher abundance and richness in the more complex forest systems, including a reforested area and an intercropping system. The families Carabidae, Scarabaeidae, Meloidae, Staphylinidae, Tenebrionidae, Curculionidae, Coccinellidae, Elateridae, Nitidulidae, and Chrysomelidae were abundant in the studied forest ecosystems.

The intercropping system and the area reforested with $S$. macrophylla had a smaller diversity of coleopteran families; however, the latter had the highest richness and dominance;

Seasonality significantly affected the diversity of coleopteran families, and the rainy season favored an increase in insect diversity.

The functional groups of coleopteran families in the ecosystems harboring $S$. macrophylla in Eastern Amazon were Anobiidae, Cerambycidae, Bostrichidae, Brentidae, Buprestidae, Curculionidae, Elateridae, Chrysomelidae, and Lagriidae as potential pests; Nitidulidae, Scarabaeidae, Tenebrionidae, and Passalidae as decomposers; Carabidae, Coccinellidae, Histeridae, Meloidae, Staphylinidae, Cantharidae, and Hydrophilidae as predators; and Erotylidae as pollinator.

\section{Acknowledgements}

To CNPq, Federal Rural University of Amazonia and Tramontina Belém company for the logistic and support on research development.

\section{References}

AGUIAR-MENEZES, E. de L.; AQUINO, A. M. Coleoptera terrestre e sua importância nos sistemas agropecuários. Rio de Janeiro: Seropédica, Embrapa Agrobiologia, 2005. 55 p. (Circular técnica, 206). Disponível em: https://www.bdpa.cnptia.embrapa.br. Acesso em: 20 jan. 2017.

ATHIÉ, I.; PAULA, D. C. de. Insetos de grãos armazenados: aspectos biológicos e identificação. 2. ed. São Paulo: Livraria Varella, 2002. 228 p.

AZEVEDO, F. R.; MOURA, A. M.; RODRIGUES, S. M.; ARRAIS, B. N.; NERE, D. R. Composição 
da entomofauna da Floresta Nacional do Araripe em diferentes vegetações e estações do ano. Revista Ceres, Viçosa, MG, v. 58, n. 6, p. 740-748, 2011. DOI: 10.1590/ S0034-737X2011000600010

AZEVEDO, R. A. R. F.; SANTOS, C. A. M. dos.; NERE, D. R.; MOURA, E. da. S. Análise faunística e sazonalidade de insetos edáficos em ecossistemas da Área de Proteção Ambiental do Araripe em duas estações do ano, Barbalha-CE. Revista Agro@mbiente On-line, Boa Vista, v. 10, n. 3, p. 263-272, jul./set. 2016. DOI: 10.18227/1982-8470ragro.v10i3.2910

BOSSÕES, R. R. Avaliação e adaptação de armadilhas para captura de insetos em corredor agroflorestal. 2011. Dissertação (Mestrado em Fitossanidade de Biotecnologia Aplicada) - Universidade Federal Rural do Rio de Janeiro, Rio de Janeiro.

CARVALHO, P. E. R. Mogno - Swietenia macrophylla. Colombo: Embrapa Florestas, 2007. 12 p. (Circular técnica, 140). Disponível em: http://ainfo.cnptia. embrapa.br/digital/bitstream/CNPF-2009-09/42435/1/ Circular140.pdf. Acesso em: 20 jan. 2017.

CIVIDANES, F. J.; BARBOSA, J. C.; MARTINS, I. C. F.; PATTARO, F.; NUNES, M. A.; SANTOS, R. S. Diversidade e distribuição espacial de artrópodes associados ao solo em agroecossistemas. Bragantia, Campinas, v. 68, n. 4, p. 991-1002, 2009. DOI: 10.1590/ S0006-87052009000400020

CIVIDANES, F. J.; SANTOS-CIVIDANES, T. M. Distribuição de Carabidae e Staphylinidae em agroecossistemas. Pesquisa Agropecuária Brasileira, Brasília, v. 43, n. 2, p. 157-163, 2008. DOI: 10.1590/ S0100-204X2008000200001

CORNELISSEN, T. G.; FERNANDES, G. W. Induced defences in the neotropical tree Bauhinia brevipes (Vog.) to herbivory: effects of damage-induced changes on leaf quality and insect attack. Trends in Ecology and Evolution, Berlim, v. 15, n. 4, p. 236-241, 2001. DOI:10.1007 / s004680100101

CORREIA, R. G. Entomofauna Edáfica $e$ Armazenamento de Liteira em Cultivos de Swietenia Macrophylla (King) na Amazônia Oriental. 2018. Tese (Doutorado) - Universidade Federal Rural da Amazônia, Belém. Recuperado de repositorio.ufra.edu.br/jspui/ handle/123456789/267

COSTA, L. L.; MARTINS, I. C. F.; BUSOLI, A. C.; CIVIDANES, F. J. Diversidade e abundância de artrópodes predadores associados a diferentes cultivares de algodoeiro. Pesquisa Agropecuária Tropical, Goiânia, v. 40, n. 4, p. 483-490, 2010. DOI: 10.5216/pat. v40i4.6720
COULSON, R. N.; WITTER, J. A. Forest entomology: ecology and management. In: COULSON, R. N.; WITTER, J. A. Principles of population modification and regulation using artificial and natural agents. New York: John Wiley e Sons, 1984. p. 193-251.

EISENHAUER, N.; MILCU, A.; SABAIS, C. W.; SCHEU, S. Animal ecosystem engineers modulate the diversity-invasibility relationship. Public Library of Science ONE, São Francisco, v. 3, n. 10, p. 3489-3497, 2008. DOI: 10.1371/ journal.pone.0003489

ENGELBRECHT, I. A. Invertebrate species inventories in protected area management: are they useful? African Entomology, Cidade do Cabo, v. 18, n. 2, p. 235-245, 2010. DOI: $10.4001 / 003.018 .0203$

FRANCO, A. C. Ecophysiology of woody plants. In: OLIVEIRA, P. S.; MARQUIS, R. J. (Ed.). The cerrados of Brazil: ecology and natural history of a neotropical savanna. Irvington: Columbia University Press, 2002. p. 178-197.

GANHO, N. G.; MARINONI, R. C. A diversidade inventarial de Coleoptera (Insecta) em uma paisagem antropizada do Bioma Araucária. Revista Brasileira de Entomologia, Curitiba, v. 49, n. 4, p. 535-543, 2005. DOI: $10.1590 / \mathrm{S} 0085-56262005000400014$

GANHO, N. G.; MARINONI, R. C. A variabilidade espacial das famílias de Coleoptera (Insecta) entre fragmentos de Floresta Ombrófila Mista Montana (Bioma Araucária) e plantação de Pinus elliottii Engelmann, no Parque Ecológico Viva Floresta, Tijucas do Sul, Paraná, Brasil. Revista Brasileira de Zoologia, Curitiba, v. 23 , n. 4 , p. $1159-1167,2006$. DOI: 10.1590/S010181752006000400024

GARDNER, A. T.; HERNÁNDEZ, M. I. M.; BARLOW, J.; PERES, C. A. Understanding the biodiversity consequences of habitat change: the value of secondary and plantation forests for Neotropical dung beetles. Journal of Applied Ecology, London, v. 45, n. 1, p. 1-11, 2008. DOI: $10.1111 /$ j.1365-2664.2008.01454.x

GOMES, G. B.; COSTA, E. M.; ARAÚJO, E. L.; SALES JÚNIOR, R.; SILVA, F. E. L. Levantamento preliminar da entomofauna associada à cultura da melancia no semiárido do Rio Grande do Norte. Revista Agropecuária Científica no Semiárido - ACSA, Campina Grande, v. 8, n. 2, p. 12-15, 2012. DOI: 10.30969/acsa.v8i2.177

HAMMER, O.; HARPER, D. A. T. PAST: Paleontological statistics. Oslo: Blackwell, 2006. Available at: http:// folk.uio.no/ohammer/past/. Accessed at: 23 maio 2017.

INSTITUTO NACIONAL DE METEOROLOGIA INMET. $2^{\circ}$ Distrito de Meteorologia, consulta genérica. Estação automática A248 Capitão Poço/PA. Serviço 
Nacional de Informações Hidro Meteorológicas, SIM. 2017. Disponível em: http://www.inmet. gov.br/ climatologia. Acesso em: 20 out. 2017.

KAGEYAMA, P. Y. A Biodiversidade como ferramenta na construção de agroecossistemas. In: CONGRESSO DE BOTÂNICA, 17., 2008, Guarulhos. Anais... Guarulhos, 2008. p. 10.

LEWINSOHN, T. M.; FREITAS, A. V. L.; PRADO, P. I. Conservation of terrestrial invertebrates and their habitats in Brazil. Conservation Biology, Boston, v. 19, n. 3, p. 640-645, 2005. DOI: 10.1111/j.1523-1739.2005.00682.x

LIMA, M. G. A.; SILVA, R. P. A.; SOUSA, M. D. F.; COSTA, E. M. Diversidade de Scarabaeinae (Coleoptera: Scarabaeidae) no parque botânico do Ceará, CaucaiaCE, Brasil. Revista Agroambiente On-line, Boa Vista, v. 7, n. 1, p. 89-94, 2013. DOI: 10.18227/1982-8470ragro. v7i1.970

LIMA, R. L.; ANDREAZZE, R.; ANDRADE, H. T. A.; PINHEIRO, M. P. G. Riqueza de famílias e hábitos alimentares em Coleoptera capturados na fazenda da EMPARN - Jiqui, Parnamirim/RN. Entomobrasilis, Vassouras, v. 3, n. 1, p. 11-15, 2010. DOI: 10.12741/ ebrasilis.v11i2

MEDRI, I. M.; LOPES, J. Scarabaeidae (Coleoptera) do Parque Estadual Mata dos Godoy e de área de pastagem, no Norte do Paraná, Brasil. Curitiba. Revista Brasileira de Zoologia, Curitiba, v. 18, p. 135-141, 2001. Suplemento 1. DOI: $10.1590 / \mathrm{S} 0101-81752001000500011$

MORAES, R. C. B.; HADDAD, M. L.; SILVEIRANETO, S.; REYES, A. E. L. Software para Análise Faunística. In: SIMPÓSIO DE ENCONTRO BIOLÓGICO, 8., 2003, São Paulo. Anais... São Pedro, 2003. p. 195.

MOORE, J. C.; WALTER, D. E.; HUNT, H. W. Arthropod regulation of micro-and mesobiota in bellow-ground detrital food webs. Annual Reviews of Entomology, Palo Alto, v. 33, n. 1, p. 419-439, 1988. DOI: 10.1146/ annurev.en.33.010188.002223

NAIR, K. S. S. Tropical forest insect pests: ecology, impact, and management. Cambridge: Cambridge University Press, 2007. 424 p.

NICHOLS, E.; SPECTOR, S.; LOUZADA, J.; LARSEN, T.; AMEZQUITA, S.; FAVILA, M. E. Ecological functions and ecosystem services provided by Scarabaeinae dung beetles. Biological Conservation, Essex, v. 141, n. 6, p. 1461-1474, 2008. DOI: 10.1016/j. biocon.2008.04.011

OLIVEIRA, C. M.; FRIZZAS, M. R. Insetos de Cerrado: distribuição estacional e abundância. Boletim de Pesquisa e Desenvolvimento, Fortaleza, v. 216, n. 1, p. 1-26, 2008.
PETRONI, D. M. Diversidade de famílias de Coleoptera em diferentes fragmentos florestais no municipio de Londrina, PR. 2008. Dissertação (Mestrado em Ciências Biológicas) - Universidade Estadual de Londrina, Londrina.

PRIMACK, R. B.; RODRIGUES, E. Biologia da conservação. Londrina: Vida, 2001. 328 p.

RAFAEL, J. A.; MELO, G. A. R.; CARVALHO, C. J. B. de.; CASARI, S. A.; CONSTANTINO, R. Insetos do Brasil: diversidade e taxonomia. Ribeirão Preto: Holos, 2011. $810 \mathrm{p}$.

ROCHA, S. C. da; QUOIRIN, M. Calogênese e rizogênese em explantes de mogno (Swietenia macrophylla King) cultivados in vitro. Ciência Florestal, Santa Maria, v. 14, n. 1, p. 91-101, 2004. DOI: 10.5902/198050981785

RODRIGUES, S. R.; MARCHINI, L. C. Ocorrência de besouros coprófagos em dois diferentes ambientes. Revista Brasileira de Entomologia, Curitiba, v. 44, n. 1/2, p. 35-38, 2000.

ROGER-ESTRADE，J.; ANGER，C.; BERTRAND, M.; RICHARD, G. Tillage and soil ecology: partners for sustainable agriculture. Soil and Tillage Research, Thiverval-Grignon, v. 111 , n. 1, p. 33-40, 2010. DOI: 10.1016/j.still.2010.08.010

SANTOS, G. G.; SILVEIRA, P. M.; MARCHÃO, R. L.; BECQUER, T.; BALBINO, L. C. Macrofauna edáfica associada a plantas de cobertura em plantio direto em um Latossolo Vermelho do Cerrado. Pesquisa Agropecuária Brasileira, Brasília, v. 43, n. 1, p. 115-122, 2008a. DOI: 10.1590/S0100-204X2008000100015

SANTOS, G. P.; VILELA, E. F.; NOGUEIRA, S. B. Estudo da bionomia e controle microbiológico de Oxydia apidania Cramer (Lepidoptera: Geometridae), desfolhador de eucalipto. Revista Árvore, Viçosa, MG, v. 3, n. 1, p. 57-74, 1979.

SANTOS, R. A.; TUCCI, C. A. F.; HARA, F. A. S.; SILVA, W. G. da. Adubação fosfatada para a produção de mudas de mogno (Swietenia macrophylla King). Acta Amazônica, Manaus, v. 38, n. 3, p. 453-458, 2008b. DOI: 10.1590/S0044-59672008000300009

SILVA, A. R. M.; TUCCI, C. A. F.; LIMA, H. N.; FIGUEIREDO, A. F. Growing doses of liming on mogno (Swietenia macrophylla King) in seedling formation. Acta Amazônica, Manaus, v. 37, n. 2, p. 195-200, 2007a. DOI: $10.1590 /$ S0044-59672007000200004

SILVA, N. A. P.; FRIZZAS, M. R.; OLIVEIRA, C. M. Seasonality in insect abundance in the Cerrado of Goiás State, Brazil. Revista Brasileira de Entomologia, Curitiba, v. 55 , n. 1, p. 79-87, 2011. DOI: $10.1590 /$ S0085-56262011000100013 
SILVA, P. G.; GARCIA, M. A. R.; MENA, N. G.; AUDINO, L. D.; NOGUEIRA, J. M.; MORAIS, L. P. de.; RAMOS, A. H. B.; VIDAL, M. B.; BORBA, M. F. S. Besouros rola-bosta: insetos benéficos. Revista Brasileira de Agroecologia, Cruz Alta, v. 2, n. 2, p. 14281432, out. 2007b.

SILVEIRA, F. A. O.; SANTOS, J. C.; VIANA, L. R.; FALQUETO, S. A.; VAZ-DE-MELLO, F. Z.; FERNANDES, G. W. Predation on Atta laevigata (Smith 1858) (Formicidae Attini) by Canthon virens (Mannerheim 1829) (Coleoptera Scarabaeidae). Tropical Zoology, Firenze, v. 1, n. 19, p. 1-7, 2006.

TABARELLI, M.; LOPES, A. V.; PERES, C. A. Edgeeffects drive tropical forest fragments towards an early-successional system. Biotropica, Val-de-Reuil, v. 40 , n. 6 , p. 657-661, 2008. DOI: 10.1111/j.17447429.2008.00454.x
THOMAZINI, M. J.; THOMAZINI, A. P. B. W. A fragmentação florestal e a diversidade de insetos nas florestas tropicais úmidas. Rio Branco: EMBRAPA, 2000. (Circular técnica, 57). 21 p. Disponível em: http://ainfo.cnptia.embrapa.br/digital/bitstream/CPAFAC/7287/1/doc57.pdf. Acesso em: 10 jan. 2017.

TRIPLEHORN, C. A.; JOHNSON, N. F. Estudos dos insetos. 7. ed. São Paulo: Cengage Learning, 2011. 809 p.

VARCHOLA, J. M.; DUNN, J. P. Influence of hedgerow and grassy field borders on round beetle (Coleoptera: Carabidae) activity in fields of corn. Agriculture, Ecosystem \& Environment, London, v. 83, n. 1/2, p. 153163, 2001. DOI: $10.1016 / \mathrm{S} 0167-8809(00) 00249-8$

ZALAZAR, L.; SALVO, A. Entomofauna associada a cultivos hortícolas orgânicos y convencionales em Córdoba, Argentina. Neotropical Entomology, Londrina, v. 36 , n. 5 , p. $765-773$, 2007. DOI: 10.1590/S1519566X2007000500019 
